\title{
TRAPPED BETWEEN CONCENTRATION AND COHESION? - OVERCOMING THE DICHOTOMOUS NATURE OF STRATEGIC SPATIAL DEVELOPMENT WITHIN THE BALTIC SEA REGION
}

\author{
TOMAS HANELL \\ Eurofutures Finland \\ Dönsbyvägen 132, 10300 Karis \\ FINLAND \\ tomas.hanell@eurofutures.fi
}

\begin{abstract}
Rapid economic growth in the BSR has been followed by increasing internal regional polarisation. Due to the small size and marginal position of many BSR countries, consistent policies aiming at creation of agglomeration effects are on a normative basis more than justifiable. This need for concentrational efforts should be weighted against the trade-off on escalating territorial polarisation, especially between metropolitan or other urban areas on the one hand, and rural or peripheral areas on the other. The concept of territorial specifities provides possibilities for a common BSR arena for developing shared policies that could navigate between the demands of the dichotomous development processes of the region. Particularly strategies aiming at larger secondary cities with their extended hinterlands appear viable and may provide one first step on this path.
\end{abstract}

Key words: Baltic Sea Region, cohesion, metropolitan areas, polarisation, specific types of regions, secondary cities

\section{INTRODUCTION}

Territorial development policies in the Baltic Sea Region (BSR) are faced with two dichotomous development options. On the one hand the smallness and marginal position in the European territory of most BSR countries implies that concentration of activities is in economic terms a justified option. On the other hand many of these same countries are in the frontline of EU when it comes to increasing regional polarisation.

Combating such opposite development tendencies via targeted policies is challenging. Territorial specifities are gaining increasing attention in European policies, as is evident e.g. in the Green Paper on Territorial Cohesion, 5th Report on Economic, Social and Territorial Cohesion, or Article 174 in the Treaty on the Functioning of the European Union. In these, the specific endowments of different territories are viewed as constituting a (currently underutilised) development potential.

This paper addresses the dichotomous development challenge of the need for both agglomerative as well as cohesive policies in the BSR. It does so by applying a focus on the territorial specifities 
of the region, where particular attention is given to that of secondary city development. Currently none of the BSR countries have unambiguous policy instruments directed specifically towards secondary cities, and the paper seeks to highlight the possibilities for better harvesting underutilised potential in secondary cities while at the same time increasing overall territorial cohesion in their respective countries. At the onset of the article, an account of current spatial tendencies in the BSR is provided.

\section{INCREASING MACROREGIONAL COHESION}

The Baltic Sea Region hosts a long standing historic legacy of economic integration. This process began with the hanseatic trade league and was partially disrupted by the Cold War division of the region into eastern and western parts. However, remnants of this division still today partly sustain. Apart from Russia and Belarus, all economies bordering the Baltic are now economically integrated into the EU/EEA Single Market, albeit in praxis at differing intensities. Despite this, the historic legacy of the 50 year divide is still clearly visible.

This gap is however diminishing rapidly. Throughout the 1990s and much of this millennium economic growth rates of the eastern BSR countries have with very few exceptions been superior to those in the west and the same pattern has continued right up till the economic crisis of 2008 (Figure 1). During the current decade right up till 2007, economic growth in the eastern BSR has been twice or even thrice as fast as in the West and thus closing rapidly in on the substantial welfare gap.

The key driver in the economic development of the BSR varies from country to country, but some common patterns are discernible. The relative prosperity of the BSR stems primarily from a high level of labour utilisation, i.e. substantial proportions of the working age population are actually employed and work comparatively long hours. The eastern parts of the region have correspondingly high rates in comparison with other CEE countries, especially when considering the hours worked per employee (Baltic Development Forum, 2006 and 2007). Contrary to popular belief, labour productivity in the BSR is not, with the exception of Norway, particularly high. In 2006, GDP per person employed in Finland (which has the highest in the BSR after Norway's 60\%) was only $11.5 \%$ above the EU27 average and surpassed by seven other Member States. At the other end of the scale Latvia and Lithuania in particular had a labour productivity less than $60 \%$ of the European Union average.

Despite the exceptionally rapid growth in the east, the welfare gap across the Baltic Sea persists and GDP per capita in the eastern BSR countries is still some 4-5 times lower than for their Western counterparts. In 1995 the ratio between the W-BSR and E-BSR was roughly 3 to 1 whereas this ratio decreased in ten years to approximately $2 \frac{1}{2}$ to 1 . If the relative production value of the two groups of countries would change linearly at a similar rate as after 1995, this gap would be closed in some thirty years. Such linearity of growth, however, is highly unlikely. On the other hand, the prime example of e.g. Ireland shows, that change can at times occur very rapidly through consistent targeted policy combined with favourable underlying conditions for growth.

As is also visible from Figure 1, the economies of particularly the Baltic States have not proven to be very resilient to the current economic downturn, but also larger BSR economies such as Russia have taken a severe beating. Economic growth in Poland on the other hand has continued on a par with the rates prior to the crisis. This implies that in the past two years the economic welfare gap in the BSR has for the first time in two decades actually widened. 


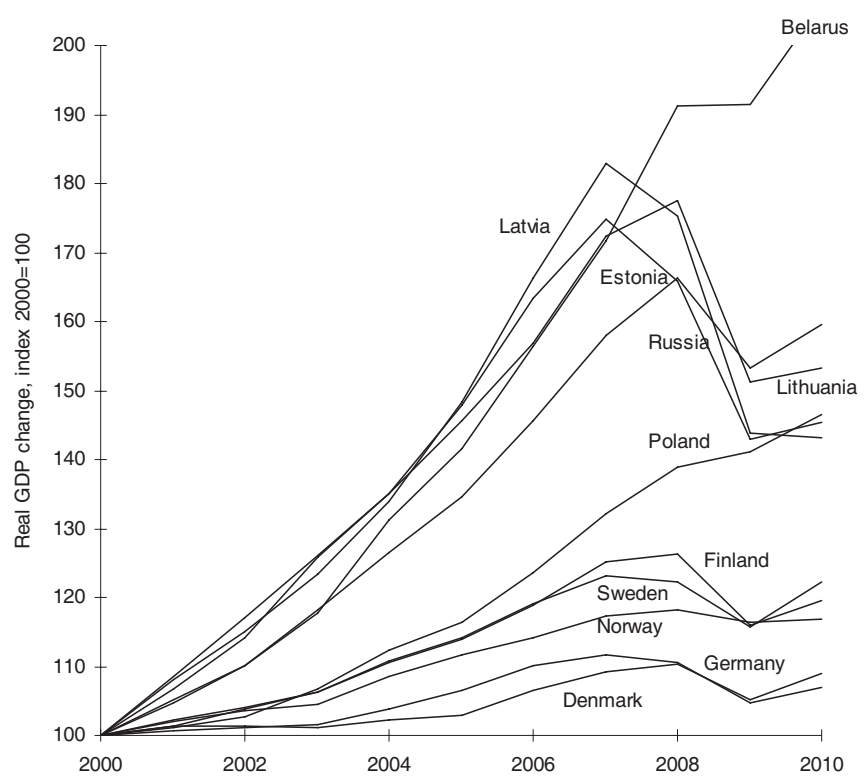

Figure 1: Real GDP change in BSR countries 2000-2010, index 2000=100

Data source: World Bank

Regardless of the overall more modest growth rates, also the western BSR countries - or specifically the Nordic ones - have been among the top European economic performers in the 2000s. In spite of this rapid overall growth in the entire BSR ${ }^{1}$, as an economic entity the Baltic Sea Region is still only a moderate European player. The size of the entire BSR economy (of which the four Nordic countries account for more than a half) is smaller than that of France despite a population nearly double the size. Unlike France however, the BSR is subdivided into at least 11 different economic entities which in European comparison entails extremely small market sizes, which, to make matters even worse, are located in the European periphery. Taking all this into account, the BSR is only a marginal economic region when viewed from the European core, or indeed globally.

Nonetheless, the region, or at least the western parts of it, is thoroughly integrated into the global economy. The regions' total share of world exports are some 50 percent higher than its share of world GDP. According to the Baltic Development Forum's State of the Region Report 2006, these high exports are slowly undergoing a gradual shift from exports of goods to exports of services.

The level of trade integration within the BSR is also fairly high, but again, disharmonic. Trade flows within the region are dominated by west-west trade (accounting for about half of all BSR trade), whereas the integrative east-west/west-east trade remains rather more modest. Partly this discrepancy results from the fact, that much of the "standard" trade flows are disrupted by especially Nordic-Baltic and German-Polish mergers, buyouts and other forms of direct investment. This in turn leads to a less statistically recorded trade. However, the relative share of the east-west/west-east trade is rapidly changing, much as the result of increased petrochemical exports from Russia (Table 1).

${ }^{1}$ Considering only the BSR parts of Germany and Russia. 


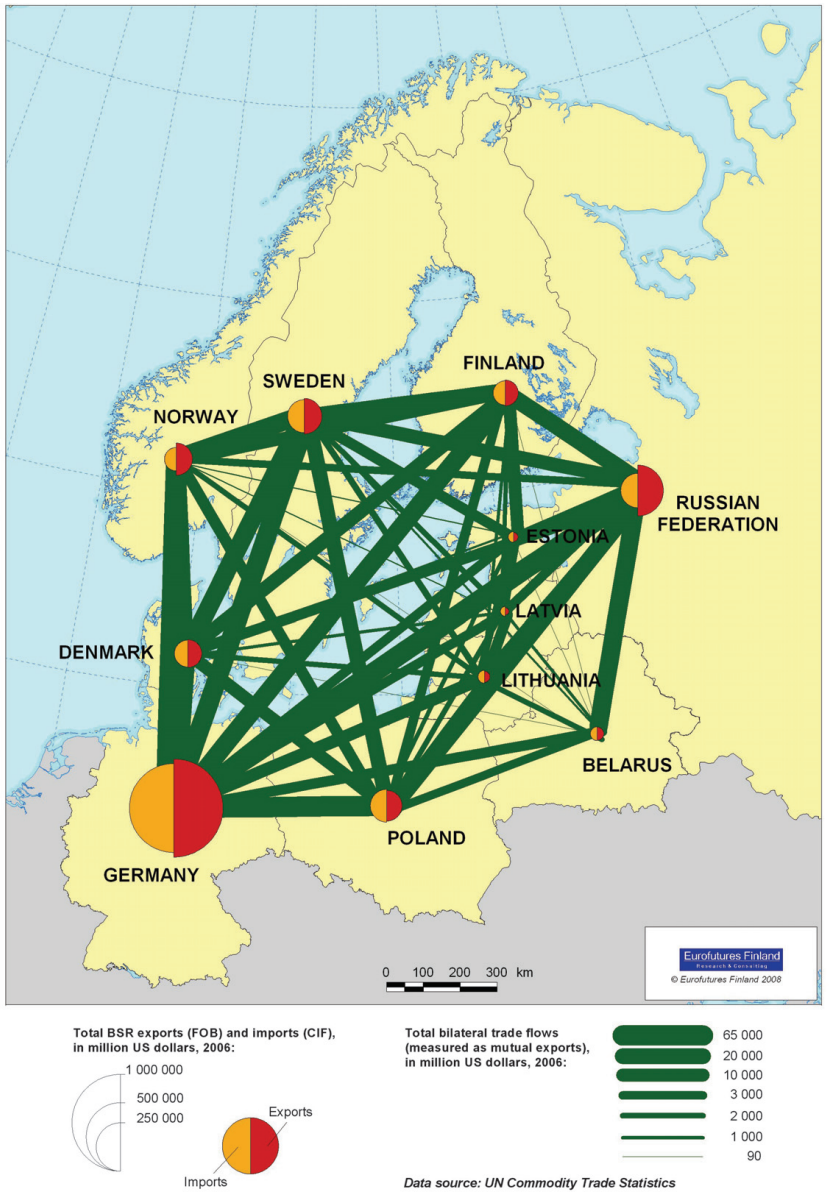

Figure 2: Trade flows in the Baltic Sea Region Source: Hanell, 2009, p. 524

Table 1: Macro regional trade flows in the BSR in 2002 and 2006

\begin{tabular}{lrrrrr}
\hline & \multicolumn{4}{c}{ Total bilateral trade $^{1}$} \\
\cline { 2 - 3 } & \multicolumn{2}{c}{ In million $\$$ U.S. ${ }^{2}$} & & Share (\%) of BSR total \\
\cline { 2 - 3 } \cline { 6 - 7 } & 2002 & 2006 & & 2002 & 2006 \\
East-East Trade & 24900 & 60800 & & 12.1 & 13.9 \\
West-West Trade & 105600 & 190900 & & 51.4 & 43.6 \\
East-West Trade & 75000 & 185800 & & 36.5 & 42.5 \\
Total intra-BSR trade & 205500 & 437500 & & 100.0 & 100.0
\end{tabular}

${ }^{1}$ Measured as mutual exports

2 In current prices

Data source: UN Commodity Trade Statistics

Source: Hanell, 2009, p. 524 
All in all, trade flows in the region are dominated by Nordic-German and intra-Nordic trade on the one hand and German-Russian trade on the other (Figure 2). The Baltic States, although more dependent on the BSR as an export market than the other countries, are small players in the overall context. For especially Russia but also Norway, exports to the BSR are considerably larger than imports from it, and furthermore largely dependent on petrochemical products.

Similar discrepancy is also evident in other forms of economic flows. Foreign Direct Investment (FDI) for example displays an even larger relative west-to-west integration whereas integrative east-west / west-east remains minuscule in comparison (BDF, 2006). Groth \& al (2008) indicate that also the intra-industry trade, which is a measure of how well different industries are integrated with one another, shows a large discrepancy between the east and the west BSR.

In terms of structural differences the BSR displays also in European terms a rather unique palette of discrepancies across the Baltic. In economic terms this is highly visible e.g. in the dualistic economic structures in relation to the knowledge economy. Whereas most western BSR countries are European top performers in virtually all measurable fields of the knowledge and innovation economy, this has yet to be materialised at the other shore of the sea (Hanell \& al., 2006)

\section{INCREASED NATIONAL POLARISATION}

If the persisting east-west dichotomy of the BSR acts as a dividing barrier, then the internal core-periphery dichotomy creates a common sphere for action for all countries in the region. Spatial polarisation in the Baltic Sea Region increasingly predominates across virtually all fields of the society, evident among others in demography, economic development, economic vulnerability, innovation, entrepreneurship, the knowledge economy, lack of polycentric urban structures, social development, and so on, virtually ad infinitum. This process, of which similar developments can be found across Europe, has despite small temporal breathers steadily been on the march for at least a decade or so and acts as a countering force to decreasing differences between the countries (Hanell, 2005; Schmitt \& al, 2008).

This result of this process is partly evident when examining disparities 2 in e.g. GDP per inhabitant over the last decade (Figure 3). During the period up till about 2005 an increase in regional polarisation has occurred in all EU Member States in the BSR except for Finland, Sweden and Germany. Similar tendencies are most likely evident also for Russia and Belarus although no comparable data exist to depict this. The most alarming development can be found in Latvia and Estonia, where disparities have increased drastically from a situation where they already at the onset were the largest

${ }^{2}$ For a given BSR country, the dispersion of regional GDP is defined as the sum of the absolute differences between regional and national GDP per inhabitant (measured at current market prices), at NUTS level 3, weighted with the regional share of population. The value of the dispersion of GDP per inhabitant is zero, if the values of regional GDP are identical in all regions of the country, and it will show, ceteris paribus, an increase, if the differences between the values of regional GDP per inhabitant among regions are rising.

The indicator however is sensitive to the regional delimitations used. Therefore, it tends to reflect the number and bounding of regions in a given member state rather than actual disparities within it. More concretely, countries (such as Latvia) where some urban areas are delimited narrowly generally tend to display larger GDP dispersion, and vice versa. Furthermore, this indicator is very sensitive to outliers (e.g. capitals), which, albeit problematic, do not depict the true state of cohesion in a country on the whole. Also, this indicator does not take into account cross-border differences within countries. The lack of territorial cohesion would be much more acute in e.g. Italy if rich and poor regions would directly border each other, rather than in the current case, where wealth decreases only gradually in small steps when moving south along the Italian peninsula.

The indicator can however be used a crude measure of changes over time in territorial cohesion (i.e. increasing, decreasing), provided that the regional classification remains unchanged. 
in the BSR. The statistically discernible decrease in the Latvian case starting in 2005 is however by and large explained only by increased value-added in the region surrounding Riga.

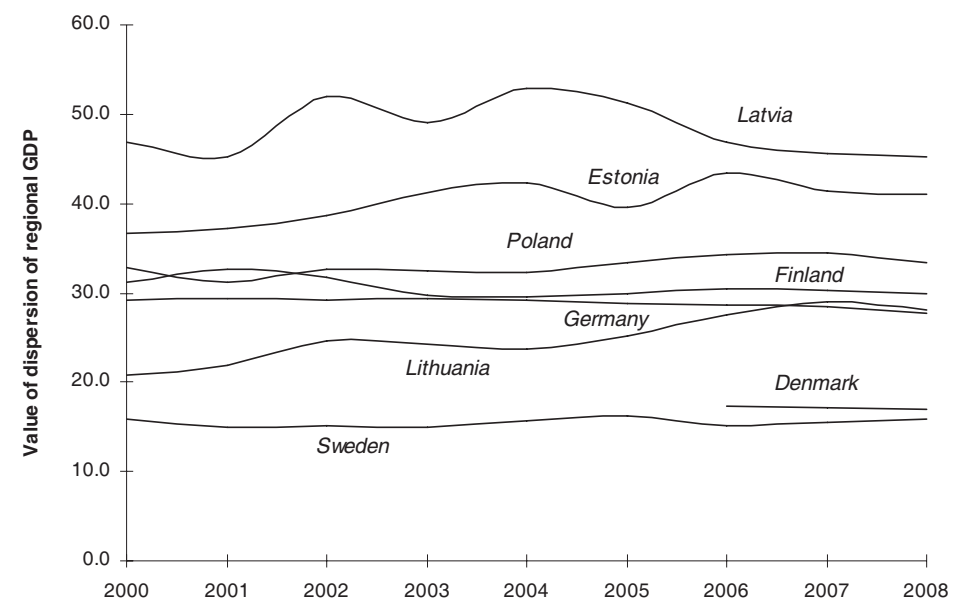

Figure 3: Dispersion of regional GDP at NUTS level 3 in the BSR 2000-08 Data source: Eurostat

A more refined pattern emerges when studying the actual spread of regional GDP at the same territorial level (Figure 4). Whereas most western BSR countries have not seen an increase in regional disparities throughout the last decade, all eastern BSR countries have. From the illustration it also becomes evident that not only the capital regions are pulling apart, but there has also been a gradual relative downshifting of the poorest regions in some of these countries (particularly Lithuania and Estonia).

GDP per capita in BSR countries 2000 and 2007, NUTS level 3

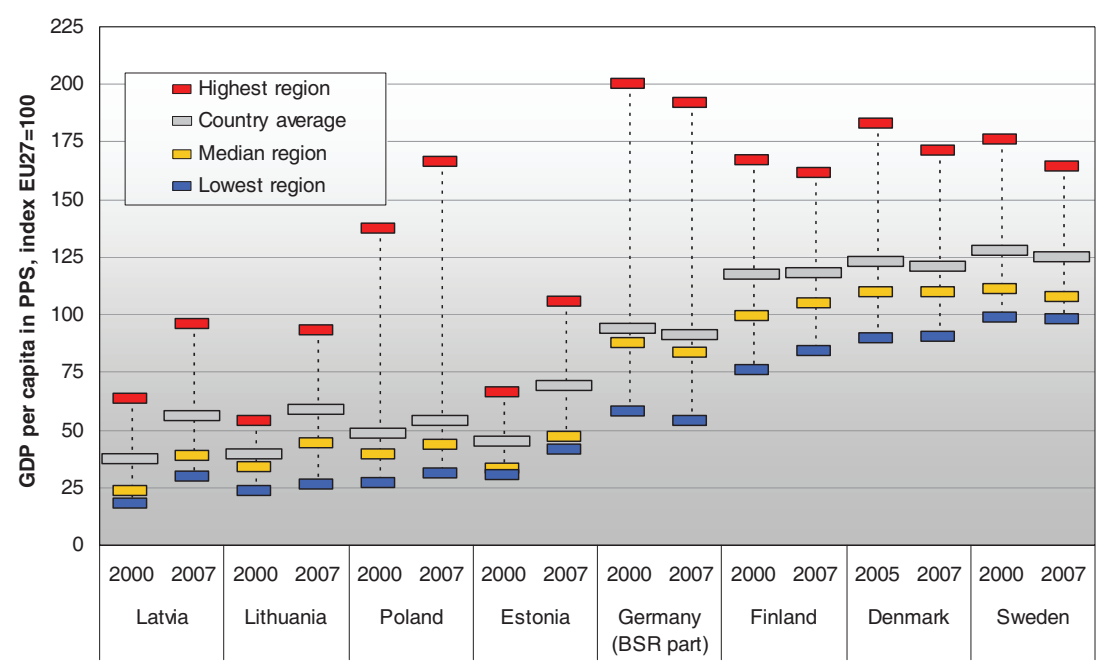

Figure 4: Distribution of GDP per capita in BSR countries 2000 and 2007

Data source: Eurostat 
Similar concentrational tendencies are also discernible with regard to e.g. employment. Disregarding the obvious national differences that stem from differing economic cycles on the one hand, and the Polish case on the other, city size remains an important factor in explaining new job creation. In general, the larger the city, the more favourable has been the development of its employment. To make matters worse, there is an ongoing process of labour reorganisation in the BSR where agricultural jobs lost in peripheral regions and manufacturing ones in industrial regions are being replaced by service sector jobs in metropolitan areas and other large cities. This transition process cannot but help to reinforce the ongoing shifts in the settlement structure of the region and to forward the increasing territorial polarisation.

\section{THE DICHOTOMY OF DUALISTIC GOAL SETTING}

Cities and urban regions are today the main engines for economic growth and competitiveness in Europe. This holds especially true for regions with a comparatively small population and a sparse settlement structure where a concentration of efforts is often the primary means to address the lack in volume. In many respects the BSR fits this pattern, albeit internal variations with regard to the settlement pattern do exist, roughly embodied in a distinct north-south dichotomy.

The uniqueness of the BSR in comparison with Europe's other meso-regions stems from a combination of its specific location and spatial structure. The regions is positioned between the densely populated continental Europe on the one hand and sparsely populated sub arctic areas on the other, divided by apparently one of the largest European east-west welfare gaps, and with some exceptions (such as Poland) some of the most monocentric settlement structures in entire Europe.

Many of the BSR countries are small in economic terms and are thus often simply unable to compete on a par with the major European economies, let alone globally. Due to their small size and marginal position in the European space, consistent policies aiming at creation of agglomeration effects are more than justifiable. In some cases the lack of agglomeration economies can be reduced by increasing cooperation, in other cases it can not. It is evident that such agglomerational policies have been beneficial in partly reducing disparities between the countries of the BSR.

This need for concentrational efforts must then be weighted against the trade-off on increasing internal territorial polarisation, especially between metropolitan or other larger urban areas on the one hand, and rural or peripheral areas on the other. Examples from other parts of the world, such as Iceland, show that the concentrational forces will, what it seems, act unconstrained everlastingly if left alone. The question thus remains whether this type of concentration is sustainable or even economical in the long run.

Strategies that are able to address the dichotomous nature of the BSR are thus in dire need. The section hereunder addresses some tentative development options.

\section{TERRITORIAL DIFFERENTIATION AS A COMMON POLICY AGENDA?}

In the BSR as elsewhere, the distinctive role of each region in its national socioeconomic context differs substantially depending on from which part of the region it is being observed. Some common traits are nonetheless discernible.

The largest cities and metropolitan areas are without doubt the main engines of BSR development. The concentration of economic activity, population, political and corporate decision-making, labour, foreign direct investment, knowledge, R\&D and innovation to the metropolitan areas of the BSR is 
substantially, higher than in many other countries of Europe. For example, more than $90 \%$ of the headquarters (HQ's) of the largest BSR enterprises are located in metropolitan areas, primarily in the western BSR. In the eastern BSR the concentration to these areas is not as marked, as $60 \%$ of the 40 largest eastern BSR HQ's are located in metropolitan areas, most of the remaining ones are however also in large Polish cities such as Krakow or Wroclaw (Hanell \& Neubauer, 2005). The social development of the cities is also of great interest, as these are the areas that most likely - at least in the foreseeable future - will steer the economic and societal development of the region. The key challenge for the metropolitan areas is how to remain competitive or to gain competitiveness on the European arena.

The BSR, east and west alike, hosts a large range of medium-sized towns and urban regions that due to historical reasons are hampered by mono-industrial economic structures, which render them especially vulnerable to external shocks and the slow grinding forces of globalisation. For these cities and regions the diversification of the economy and/or a gradual increase of the knowledge component in their manufacturing industries will, if successful, most likely prove to be the most feasible solution in the long term. At the same time, this would imply that such areas are becoming increasingly interconnected with the global economy which also poses considerable challenges. The small size and the long distances as well as the current "specialisation" render it difficult to counterbalance their small size with increased networking and cooperation. However, as few other options are at hand, this will most likely remain a strategy for many of such areas at least in medium term.

The core rural areas, primarily in the southern BSR, are handicapped by lack of opportunities for economic development outside the sphere of primary production, often low levels of education, and substandard infrastructure which results in bad accessibility and connectivity to larger centres, despite not being amongst the most peripheral regions. Two distinct trajectories for these areas in general seem likely. Either their relative position will continue to decline further or then some form of urbanisation will occur. The latter could happen via two separate paths. On the one hand an in situ urbanisation e.g. via increased accessibility to urban labour markets could be possible for some of these areas. On the other hand an endogenous structural change of the local economy could take place, which would transform their economic base without tying them too rigorously to larger metropolitan areas.

The most sparsely populated areas again, primarily in the north of the BSR, are handicapped by a lack of possibilities for agglomeration economies, rather few and as a result of the large distances scattered centres of knowledge which hinder networking and cooperation. Furthermore, especially in the Nordic countries, much of the employment in these areas is overly dependent on the public sector. In the most peripheral areas in particular, the structural problems are exacerbated by rapid out-migration towards the south or selected university centres in between.

On the European policy arena, increasing interest is being paid to such distinctive regional features. In the 2008 Green Paper on Territorial Cohesion (European Commission, 2008) regional distinctiveness was addressed through "Regions with specific geographical features", where mountain regions, island regions, and sparsely populated regions as well as coastal and outermost ones were singled out as facing "particular development challenges". Likewise, the 5th Report on Economic, Social and Territorial Cohesion (European Commission, 2010) specifically addressed six different main categories of regions: urban-rural, metro regions, order regions, mountain regions, island regions, and sparsely-populated regions. In addition also e.g. the Treaty on the Functioning of the European Union's Article 174 acknowledged the further specific geographical endowments of "plains, river valleys and lake basins and other types of territories" that suffer from severe and permanent 
natural or demographic handicaps. The rationale to single out such types of regions has clearly shifted from a formerly narrow lobbying perspective to a wider appreciation of the need to better exploit local territorial assets and hence to contribute to common EU welfare.

From a BSR perspective one question is whether such acknowledgements of territorial specifities could be utilised to counteract regional polarisation without losing momentum in overall economic development of these countries. Many of such types of regions listed above are indeed shared between most BSR countries and count tentatively be developed in the framework of a common policy arena. Table 2 summarises $^{3}$ the economic contribution between 2000 and 2008 of the six ${ }^{4}$ specific types of regions put forth for the EU MS of the $\mathrm{BSR}^{5}$. The actual distribution of these regions is depicted in Figure 5 .

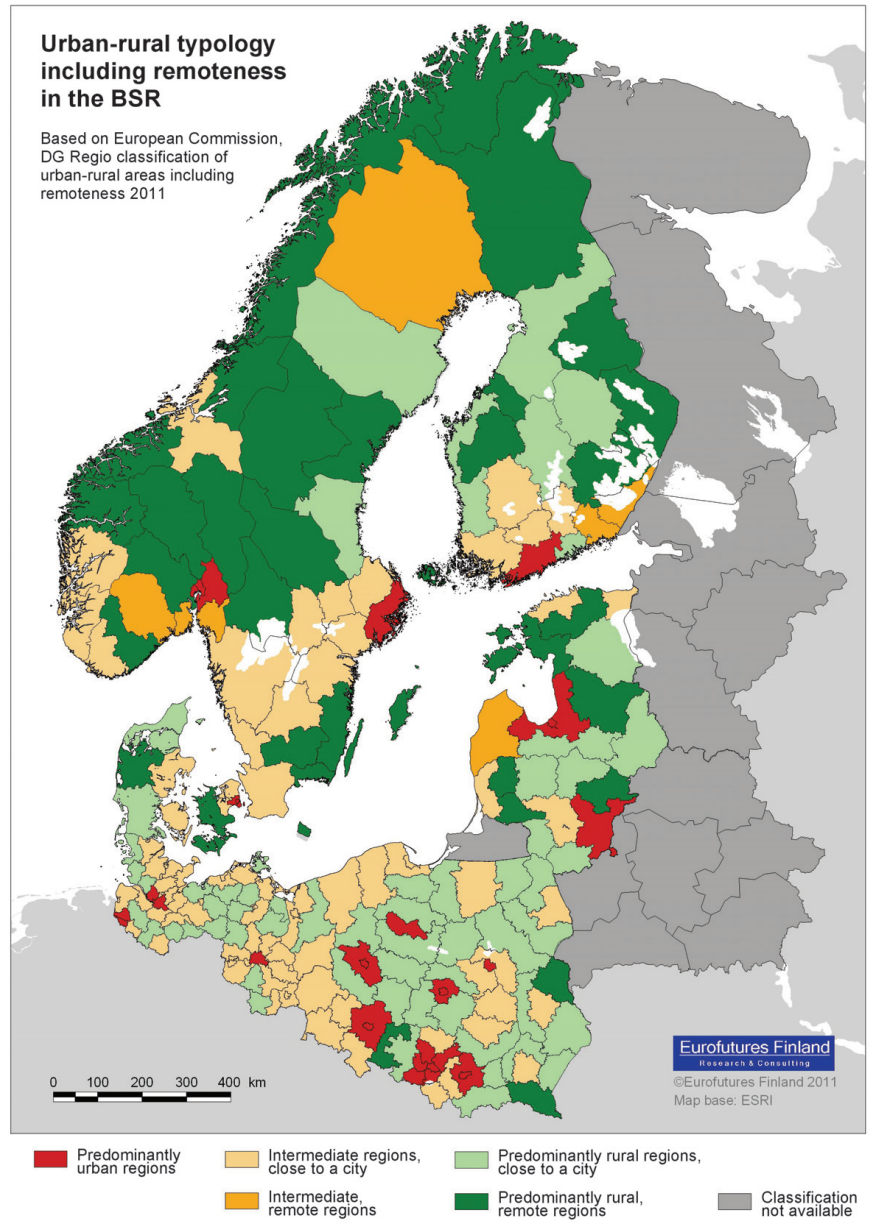

Figure 5: The EU Commission urban-rural typology applied on the BSR

3 The utilised regional typologies stem from the European Commission, DG Regio, 2011. See e.g. http://epp.eurostat. ec.europa.eu/statistics_explained/index.php/Regional_typologies_overview

${ }^{4}$ In fact seven, as border regions are further divided into two sub categories.

5 Data for Belarus and the Russian regions of the BSR are excluded. 
Table 2: Economic contribution of different types of BSR regions 2000-2008

\begin{tabular}{|c|c|c|c|c|c|c|c|c|c|c|c|c|c|c|c|c|c|c|}
\hline \multirow{2}{*}{$\begin{array}{r}\text { Typology } \\
\text { Class }\end{array}$} & \multicolumn{9}{|c|}{ Share (\%) of total BSR* Gross Domestic Product } & \multicolumn{9}{|c|}{ Share (\%) of total BSR* Employment } \\
\hline & 2000 & 2001 & 2002 & 2003 & 2004 & 2005 & 2006 & 2007 & 2008 & 2000 & 2001 & 2002 & 2003 & 2004 & 2005 & 2006 & 2007 & 2008 \\
\hline \multicolumn{19}{|l|}{ Urban/rural including remoteness } \\
\hline Predominantly urban regions & 38.8 & 38.6 & 38.9 & 38.7 & 38.6 & 39.0 & 38.8 & 39.0 & 39.0 & 32.1 & 32.4 & 32.6 & 32.7 & 32.9 & 32.9 & 33.1 & 33.2 & 33.2 \\
\hline Intermediate regions, close to a city & 33.8 & 33.9 & 33.8 & 34.0 & 33.8 & 33.7 & 33.9 & 33.9 & 33.7 & 34.5 & 34.5 & 34.4 & 34.4 & 34.5 & 34.4 & 34.5 & 34.5 & 34.5 \\
\hline Intermediate, remote regions & 2.3 & 2.3 & 2.3 & 2.3 & 2.3 & 2.4 & 2.4 & 2.3 & 2.4 & 1.8 & 1.8 & 1.8 & 1.8 & 1.8 & 1.8 & 1.8 & 1.8 & 1.8 \\
\hline Predominantly rural regions, close to a city & 15.5 & 15.6 & 15.7 & 15.7 & 15.8 & 15.6 & 15.4 & 15.5 & 15.6 & 22.9 & 22.4 & 22.2 & 22.2 & 21.9 & 21.9 & 21.7 & 21.7 & 21.9 \\
\hline Predominantly rural, remote regions & 9.6 & 9.5 & 9.4 & 9.4 & 9.4 & 9.4 & 9.5 & 9.3 & 9.4 & 8.8 & 8.8 & 8.9 & 8.9 & 8.8 & 8.9 & 8.8 & 8.7 & 8.6 \\
\hline \multicolumn{19}{|l|}{ Metro regions } \\
\hline Capital city region & 28.8 & 28.7 & 28.8 & 28.6 & 28.6 & 29.2 & 29.3 & 29.4 & 29.2 & 22.8 & 22.9 & 23.0 & 23.0 & 23.1 & 23.1 & 23.3 & 23.4 & 23.5 \\
\hline Second tier metro region & 25.3 & 25.3 & 25.6 & 25.5 & 25.5 & 25.3 & 25.1 & 25.1 & 25.1 & 22.8 & 23.1 & 23.4 & 23.4 & 23.6 & 23.7 & 23.7 & 23.7 & 23.7 \\
\hline Smaller metro region & 12.3 & 12.3 & 12.1 & 12.2 & 12.1 & 12.1 & 12.0 & 12.0 & 12.1 & 15.3 & 15.1 & 14.8 & 14.7 & 14.7 & 14.6 & 14.5 & 14.5 & 14.5 \\
\hline Other regions & 33.7 & 33.7 & 33.6 & 33.6 & 33.8 & 33.5 & 33.7 & 33.6 & 33.6 & 39.2 & 38.9 & 38.9 & 38.8 & 38.6 & 38.6 & 38.5 & 38.4 & 38.3 \\
\hline \multicolumn{19}{|l|}{ Mountain regions } \\
\hline$>50 \%$ of population and $50 \%$ of surface & 3.7 & 3.8 & 3.7 & 3.7 & 3.8 & 4.0 & 4.1 & 4.0 & 4.2 & 3.8 & 3.6 & 3.5 & 3.5 & 3.6 & 3.6 & 3.7 & 3.6 & 3.6 \\
\hline$>50 \%$ of surface & 6.3 & 6.3 & 5.9 & 6.0 & 6.2 & 6.7 & 7.0 & 6.9 & 7.2 & 4.0 & 4.0 & 4.1 & 4.1 & 4.1 & 4.1 & 4.1 & 4.2 & 4.2 \\
\hline Other regions & 90.0 & 89.9 & 90.4 & 90.3 & 89.9 & 89.3 & 88.9 & 89.1 & 88.6 & 92.1 & 92.4 & 92.4 & 92.4 & 92.4 & 92.3 & 92.2 & 92.2 & 92.1 \\
\hline \multicolumn{19}{|l|}{ Island regions } \\
\hline Major island between 50,000 and 100,000 inh. & 0.1 & 0.1 & 0.1 & 0.1 & 0.1 & 0.1 & 0.1 & 0.1 & 0.1 & 0.1 & 0.1 & 0.1 & 0.1 & 0.1 & 0.1 & 0.1 & 0.1 & 0.1 \\
\hline Major island $<50,000$ inhabitants & 0.1 & 0.1 & 0.1 & 0.1 & 0.1 & 0.1 & 0.1 & 0.1 & 0.1 & 0.1 & 0.1 & 0.1 & 0.1 & 0.1 & 0.1 & 0.1 & 0.1 & 0.1 \\
\hline Other regions & 99.8 & 99.8 & 99.8 & 99.8 & 99.8 & 99.8 & 99.8 & 99.8 & 99.8 & 99.8 & 99.8 & 99.8 & 99.8 & 99.8 & 99.8 & 99.8 & 99.8 & 99.8 \\
\hline \multicolumn{19}{|l|}{ Sparsely populated regions } \\
\hline Less than $12.5 \mathrm{inh} / \mathrm{km}^{2}$ & 5.5 & 5.5 & 5.4 & 5.4 & 5.5 & 5.5 & 5.6 & 5.4 & 5.5 & 4.1 & 4.1 & 4.2 & 4.2 & 4.2 & 4.2 & 4.1 & 4.1 & 4.1 \\
\hline Other regions & 94.5 & 94.5 & 94.6 & 94.6 & 94.5 & 94.5 & 94.4 & 94.6 & 94.5 & 95.9 & 95.9 & 95.8 & 95.8 & 95.8 & 95.8 & 95.9 & 95.9 & 95.9 \\
\hline \multicolumn{19}{|l|}{ Border regions } \\
\hline $\begin{array}{l}\text { Programme area } \\
\text { Prom }\end{array}$ & 52.5 & 52.4 & 52.4 & 52.3 & 52.6 & 52.5 & 52.6 & 52.6 & 52.5 & 50.7 & 51.3 & 51.3 & 51.3 & 51.1 & 51.2 & 50.9 & 50.8 & 50.6 \\
\hline Programme area (partly) & 4.9 & 4.9 & 5.0 & 4.8 & 4.8 & 4.7 & 4.7 & 4.7 & 4.7 & 5.8 & 5.6 & 5.6 & 5.6 & 5.6 & 5.6 & 5.7 & 5.6 & 5.6 \\
\hline No programme area & 42.6 & 42.8 & 42.7 & 42.9 & 42.6 & 42.9 & 42.7 & 42.7 & 42.7 & 43.5 & 43.1 & 43.0 & 43.1 & 43.4 & 43.2 & 43.4 & 43.7 & 43.7 \\
\hline \multicolumn{19}{|l|}{ Internal/external border regions } \\
\hline Internal and external border programmes & 6.1 & 6.1 & 6.2 & 6.3 & 6.3 & 6.4 & 6.4 & 6.5 & 6.5 & 9.0 & 8.8 & 8.9 & 8.8 & 8.7 & 8.8 & 8.8 & 8.9 & 9.0 \\
\hline External border programmes & 2.9 & 3.0 & 3.0 & 3.1 & 3.1 & 3.1 & 3.2 & 3.3 & 3.3 & 4.8 & 4.8 & 4.7 & 4.7 & 4.7 & 4.8 & 4.7 & 4.8 & 4.8 \\
\hline Internal border programmes (EU + EFTA) & 48.4 & 48.1 & 48.1 & 47.7 & 48.0 & 47.6 & 47.7 & 47.6 & 47.5 & 42.7 & 43.3 & 43.4 & 43.3 & 43.2 & 43.2 & 43.1 & 42.7 & 42.5 \\
\hline Other regions & 42.6 & 42.8 & 42.7 & 42.9 & 42.6 & 42.9 & 42.7 & 42.7 & 42.7 & 43.5 & 43.1 & 43.0 & 43.1 & 43.4 & 43.2 & 43.4 & 43.7 & 43.7 \\
\hline
\end{tabular}

Data source: Eurostat

In this respect two specific types of impediments can be identified. One the one hand many of such specific types of regions are so encompassing that the specific geographical features of these regions are dwarfed by the heterogeneity of the total number of regions that they cover. Thus for instance border areas account for close to $60 \%$ of the total BSR value-added or employment and encompass a large multitude of differing regions ranging from the largest metropolitan areas to the most remote rural ones. Clearly a common BSR policy arena for such a heterogeneous group would be difficult to construct.

On the other hand several of the specific types of regions are relatively infrequent (such as island regions) and their overall economic impact remains modest when viewed from a consolidated BSR perspective. In addition, areas such as mountain regions or sparsely populated ones are concentrated to a few countries only, thus further diminishing their overall BSR significance.

The typology of urban and rural areas that address the settlement hierarchy in one form appears to confirm the overall cemented concentrative pattern of the BSR. The most urbanised regions appear to be biting an ever larger chunk of the overall economic cake. This notion is partly misleading, since an examination of the typology on metro regions, that also partly addresses issues pertaining to urban functionality, reveals that this urban concentration is particularly in employment terms concentrated not to the largest (capital) cities of the BSR, but rather to the second tier of metro regions. A more thorough country wise examination of this typology would therefore seem feasible (Table 3). The location and delimitation of these areas are also depicted in Figure 6. 


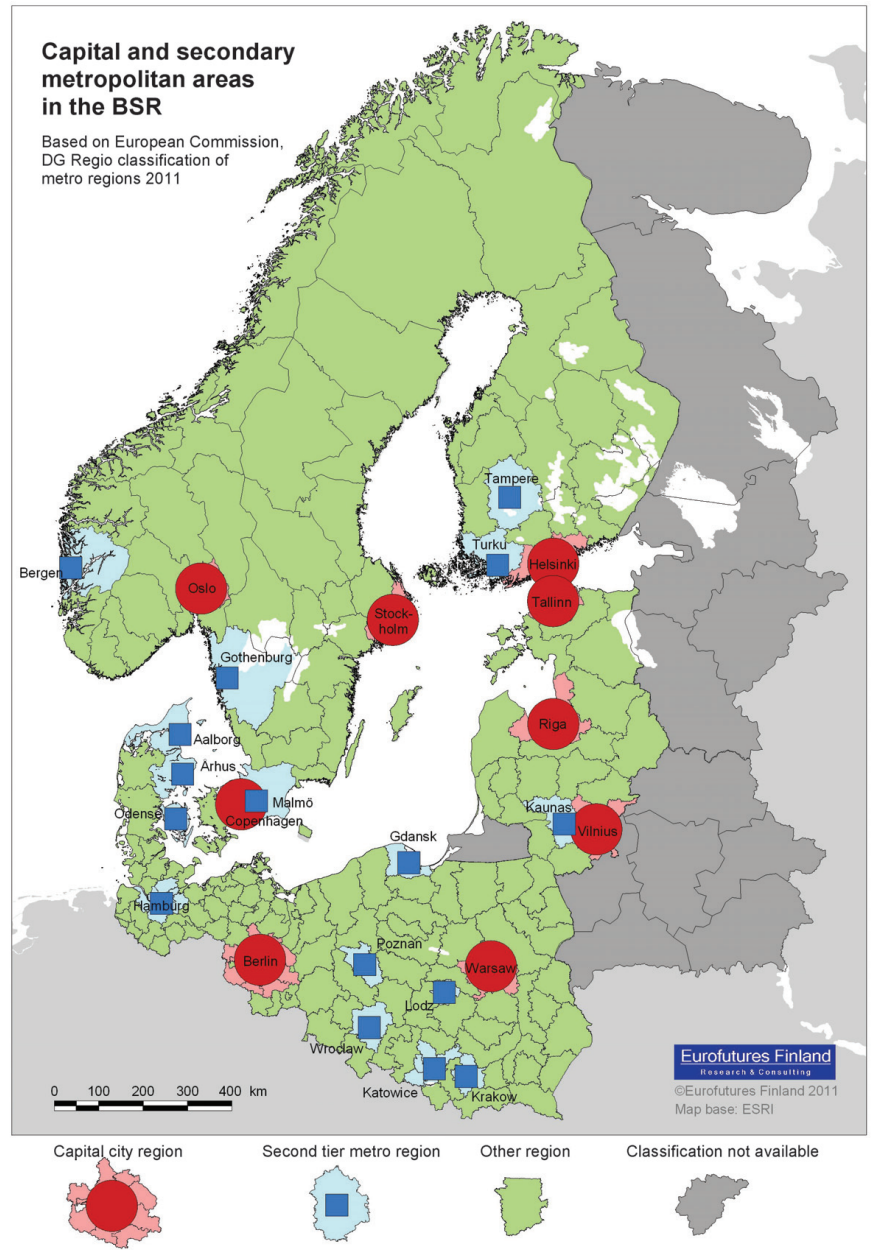

Figure 6: The EU Commission metro region typology applied on the BSR

In (the BSR parts of) Germany, Denmark and Finland second tier metropolitan areas have increased their relative share of both the national GDP as well as employment much faster than have their respective capital areas. In Poland and Sweden this applies to employment but not GDP. In such countries where "smaller metro regions" have been acknowledged, these are generally performing slightly better than the non-urban regions but worse than the second tier of metropolitan areas.

Bearing in mind (from Table 2) that the secondary cities account for nearly a quarter of all BSR value added as well as jobs, and that such areas exist in all BSR countries ${ }^{6}$, a common arena for development of such secondary cities could be deemed feasible. While much emphasis in policy development has been placed on the very largest urban concentrations in Europe, secondary cities have not gained equal attention. Many of these cities are path dependent and are curbed by historical

${ }^{6}$ The "lack" of secondary cities in the current DG Regio classification in some countries is addressed in the still ongoing ESPON project SGPTDE - Secondary Growth Poles in Territorial Development in Europe: Performance, Policies and Prospects, where Daugavpils in Latvia, Klaipeda in Lithuania, and Tartu in Estonia are being analysed as secondary cities. 
aspects that may be e.g. structural, political or institutional, and are in need of new development opportunities, national strategies for development, and governance tools that are aligned with the requirements of the current millennium (ESPON SGPTDE, 2011).

Table 3: Economic contribution of different types of metro regions in the BSR 2000-2008

\begin{tabular}{|c|c|c|c|c|c|c|c|c|c|c|c|c|c|c|c|c|c|c|c|}
\hline \multirow{2}{*}{ 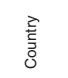 } & \multirow{2}{*}{$\begin{array}{l}\text { Typology } \\
\text { class }\end{array}$} & \multicolumn{9}{|c|}{ Share (\%) of total BSR* Gross Domestic Product } & \multicolumn{9}{|c|}{ Share (\%) of total BSR* Employment } \\
\hline & & 2000 & 2001 & 2002 & 2003 & 2004 & 2005 & 2006 & 2007 & 2008 & 2000 & 2001 & 2002 & 2003 & 2004 & 2005 & 2006 & 2007 & 2008 \\
\hline \multirow{4}{*}{ 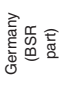 } & Capital city regions & 30.4 & 30.0 & 30.0 & 29.8 & 29.6 & 29.8 & 30.0 & 30.2 & 30.1 & 32.8 & 32.6 & 32.4 & 32.4 & 32.6 & 32.7 & 32.9 & 33.0 & 33.1 \\
\hline & Second tier metro regions & 29.5 & 30.2 & 30.3 & 30.3 & 30.4 & 30.8 & 30.3 & 30.0 & 30.3 & 23.4 & 23.7 & 23.9 & 24.0 & 24.1 & 24.2 & 24.2 & 24.3 & 24.3 \\
\hline & Smaller metro regions & 22.1 & 22.0 & 21.9 & 22.1 & 22.0 & 21.9 & 22.0 & 22.1 & 22.0 & 23.0 & 23.0 & 23.1 & 23.0 & 22.9 & 22.8 & 22.8 & 22.6 & 22.6 \\
\hline & Other regions & 18.0 & 17.8 & 17.8 & 17.8 & 18.0 & 17.6 & 17.7 & 17.6 & 17.6 & 20.8 & 20.6 & 20.6 & 20.5 & 20.3 & 20.2 & 20.1 & 20.1 & 20.0 \\
\hline \multirow{4}{*}{ 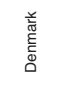 } & Capital city regions & 40.1 & 39.8 & 39.2 & 39.7 & 40.1 & 41.0 & 39.9 & 39.8 & 39.9 & 36.6 & 37.0 & 36.5 & 36.7 & 36.5 & 36.7 & 36.4 & 36.3 & 36.8 \\
\hline & Second tier metro regions & 30.5 & 30.7 & 31.1 & 30.9 & 30.5 & 30.1 & 30.7 & 30.8 & 30.9 & 32.4 & 32.2 & 32.8 & 32.8 & 32.9 & 33.0 & 32.9 & 33.2 & 33.1 \\
\hline & Smaller metro regions & $\mathrm{n} / \mathrm{a}$ & $\mathrm{n} / \mathrm{a}$ & $\mathrm{n} / \mathrm{a}$ & $\mathrm{n} / \mathrm{a}$ & $\mathrm{n} / \mathrm{a}$ & $\mathrm{n} / \mathrm{a}$ & $\mathrm{n} / \mathrm{a}$ & $\mathrm{n} / \mathrm{a}$ & $\mathrm{n} / \mathrm{a}$ & $\mathrm{n} / \mathrm{a}$ & $\mathrm{n} / \mathrm{a}$ & $\mathrm{n} / \mathrm{a}$ & $n / a$ & $\mathrm{n} / \mathrm{a}$ & $\mathrm{n} / \mathrm{a}$ & $\mathrm{n} / \mathrm{a}$ & $\mathrm{n} / \mathrm{a}$ & $\mathrm{n} / \mathrm{a}$ \\
\hline & Other regions & 29.4 & 29.5 & 29.7 & 29.5 & 29.4 & 28.9 & 29.4 & 29.4 & 29.3 & 30.9 & 30.8 & 30.7 & 30.5 & 30.6 & 30.3 & 30.7 & 30.4 & 30.1 \\
\hline \multirow{4}{*}{ 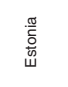 } & Capital city regions & 56.7 & 57.1 & 57.8 & 59.3 & 59.8 & 58.5 & 60.5 & 59.7 & 59.6 & 45.0 & 45.0 & 45.5 & 45.2 & 45.0 & 46.1 & 45.5 & 45.9 & 46.5 \\
\hline & Second tier metro regions & $\mathrm{n} / \mathrm{a}$ & $\mathrm{n} / \mathrm{a}$ & $\mathrm{n} / \mathrm{a}$ & $\mathrm{n} / \mathrm{a}$ & $\mathrm{n} / \mathrm{a}$ & $\mathrm{n} / \mathrm{a}$ & $\mathrm{n} / \mathrm{a}$ & $\mathrm{n} / \mathrm{a}$ & $\mathrm{n} / \mathrm{a}$ & $\mathrm{n} / \mathrm{a}$ & $\mathrm{n} / \mathrm{a}$ & $\mathrm{n} / \mathrm{a}$ & $n / a$ & $\mathrm{n} / \mathrm{a}$ & $\mathrm{n} / \mathrm{a}$ & $\mathrm{n} / \mathrm{a}$ & $\mathrm{n} / \mathrm{a}$ & $\mathrm{n} / \mathrm{a}$ \\
\hline & Smaller metro regions & $\mathrm{n} / \mathrm{a}$ & $n / a$ & $\mathrm{n} / \mathrm{a}$ & $\mathrm{n} / \mathrm{a}$ & $\mathrm{n} / \mathrm{a}$ & $\mathrm{n} / \mathrm{a}$ & $\mathrm{n} / \mathrm{a}$ & $\mathrm{n} / \mathrm{a}$ & $\mathrm{n} / \mathrm{a}$ & $\mathrm{n} / \mathrm{a}$ & $\mathrm{n} / \mathrm{a}$ & $\mathrm{n} / \mathrm{a}$ & $n / a$ & $\mathrm{n} / \mathrm{a}$ & $\mathrm{n} / \mathrm{a}$ & $\mathrm{n} / \mathrm{a}$ & $\mathrm{n} / \mathrm{a}$ & $\mathrm{n} / \mathrm{a}$ \\
\hline & Other regions & 43.3 & 42.9 & 42.2 & 40.7 & 40.2 & 41.5 & 39.5 & 40.3 & 40.4 & 55.0 & 55.0 & 54.5 & 54.8 & 55.0 & 53.9 & 54.5 & 54.1 & 53.5 \\
\hline \multirow{4}{*}{ 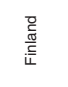 } & Capital city regions & 36.9 & 37.3 & 37.0 & 36.3 & 36.5 & 36.7 & 37.3 & 37.4 & 37.5 & 32.5 & 32.8 & 32.9 & 32.4 & 32.4 & 32.4 & 32.5 & 32.7 & 32.8 \\
\hline & Second tier metro regions & 16.5 & 16.6 & 17.3 & 17.1 & 17.2 & 17.1 & 17.0 & 17.3 & 17.1 & 16.9 & 17.0 & 17.0 & 17.2 & 17.2 & 17.3 & 17.3 & 17.4 & 17.3 \\
\hline & Smaller metro regions & $\mathrm{n} / \mathrm{a}$ & $\mathrm{n} / \mathrm{a}$ & $\mathrm{n} / \mathrm{a}$ & $\mathrm{n} / \mathrm{a}$ & $\mathrm{n} / \mathrm{a}$ & $\mathrm{n} / \mathrm{a}$ & $\mathrm{n} / \mathrm{a}$ & $\mathrm{n} / \mathrm{a}$ & $n / a$ & $\mathrm{n} / \mathrm{a}$ & $\mathrm{n} / \mathrm{a}$ & $\mathrm{n} / \mathrm{a}$ & $n / a$ & $\mathrm{n} / \mathrm{a}$ & $\mathrm{n} / \mathrm{a}$ & $n / a$ & $\mathrm{n} / \mathrm{a}$ & $\mathrm{n} / \mathrm{a}$ \\
\hline & Other regions & 46.6 & 46.1 & 45.7 & 46.6 & 46.3 & 46.2 & 45.7 & 45.3 & 45.4 & 50.5 & 50.2 & 50.1 & 50.4 & 50.4 & 50.2 & 50.2 & 50.0 & 49.9 \\
\hline \multirow{4}{*}{ 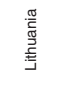 } & Capital city regions & 33.4 & 34.3 & 36.0 & 36.1 & 36.2 & 36.9 & 38.4 & 39.4 & 39.2 & 25.9 & 26.1 & 25.6 & 26.4 & 26.6 & 27.1 & 27.5 & 27.4 & 27.8 \\
\hline & Second tier metro regions & 19.1 & 19.4 & 18.8 & 19.2 & 19.0 & 19.3 & 19.2 & 19.3 & 19.4 & 19.5 & 20.2 & 20.4 & 20.3 & 20.9 & 19.6 & 20.2 & 20.4 & 19.9 \\
\hline & Smaller metro regions & $\mathrm{n} / \mathrm{a}$ & $\mathrm{n} / \mathrm{a}$ & $\mathrm{n} / \mathrm{a}$ & $\mathrm{n} / \mathrm{a}$ & $\mathrm{n} / \mathrm{a}$ & $\mathrm{n} / \mathrm{a}$ & $\mathrm{n} / \mathrm{a}$ & $\mathrm{n} / \mathrm{a}$ & $\mathrm{n} / \mathrm{a}$ & $\mathrm{n} / \mathrm{a}$ & $\mathrm{n} / \mathrm{a}$ & $\mathrm{n} / \mathrm{a}$ & $n / a$ & $n / a$ & $\mathrm{n} / \mathrm{a}$ & $\mathrm{n} / \mathrm{a}$ & $\mathrm{n} / \mathrm{a}$ & $\mathrm{n} / \mathrm{a}$ \\
\hline & Other regions & 47.5 & 46.3 & 45.2 & 44.8 & 44.8 & 43.9 & 42.4 & 41.4 & 41.5 & 54.6 & 53.6 & 54.0 & 53.3 & 52.5 & 53.4 & 52.3 & 52.2 & 52.3 \\
\hline \multirow{4}{*}{ 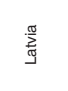 } & Capital city regions & 65.7 & 64.9 & 67.8 & 66.3 & 67.9 & 68.5 & 68.3 & 66.8 & 66.9 & 51.3 & 51.0 & 51.3 & 51.9 & 52.9 & 52.4 & 51.3 & 51.7 & 51.3 \\
\hline & Second tier metro regions & $\mathrm{n} / \mathrm{a}$ & $n / a$ & $\mathrm{n} / \mathrm{a}$ & $\mathrm{n} / \mathrm{a}$ & $\mathrm{n} / \mathrm{a}$ & $\mathrm{n} / \mathrm{a}$ & $\mathrm{n} / \mathrm{a}$ & $\mathrm{n} / \mathrm{a}$ & $\mathrm{n} / \mathrm{a}$ & $\mathrm{n} / \mathrm{a}$ & $\mathrm{n} / \mathrm{a}$ & n/a & $\mathrm{n} / \mathrm{a}$ & $\mathrm{n} / \mathrm{a}$ & $\mathrm{n} / \mathrm{a}$ & $\mathrm{n} / \mathrm{a}$ & $\mathrm{n} / \mathrm{a}$ & $\mathrm{n} / \mathrm{a}$ \\
\hline & Smaller metro regions & $\mathrm{n} / \mathrm{a}$ & $\mathrm{n} / \mathrm{a}$ & $\mathrm{n} / \mathrm{a}$ & $\mathrm{n} / \mathrm{a}$ & $\mathrm{n} / \mathrm{a}$ & $\mathrm{n} / \mathrm{a}$ & $\mathrm{n} / \mathrm{a}$ & $\mathrm{n} / \mathrm{a}$ & $\mathrm{n} / \mathrm{a}$ & $\mathrm{n} / \mathrm{a}$ & $\mathrm{n} / \mathrm{a}$ & $\mathrm{n} / \mathrm{a}$ & $n / a$ & $\mathrm{n} / \mathrm{a}$ & $\mathrm{n} / \mathrm{a}$ & $n / a$ & $\mathrm{n} / \mathrm{a}$ & $\mathrm{n} / \mathrm{a}$ \\
\hline & Other regions & 34.3 & 35.1 & 32.2 & 33.7 & 32.1 & 31.5 & 31.7 & 33.2 & 33.1 & 48.7 & 49.0 & 48.7 & 48.1 & 47.1 & 47.6 & 48.7 & 48.3 & 48.7 \\
\hline \multirow{4}{*}{ 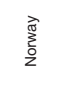 } & Capital city regions & 32.7 & 32.0 & 32.0 & 31.1 & 31.8 & 32.2 & 32.0 & 32.3 & 32.3 & 27.6 & 29.1 & 29.3 & 28.7 & 28.7 & 27.9 & 28.0 & 28.4 & 28.4 \\
\hline & Second tier metro regions & 9.3 & 9.7 & 9.3 & 9.9 & 10.0 & 10.1 & 9.9 & 10.2 & 10.2 & 9.6 & 9.4 & 9.5 & 9.7 & 9.8 & 9.8 & 9.8 & 9.8 & 9.8 \\
\hline & Smaller metro regions & 8.6 & 8.7 & 8.6 & 9.4 & 9.2 & 9.2 & 9.8 & 9.6 & 9.6 & 8.4 & 8.3 & 8.3 & 8.7 & 8.8 & 8.7 & 8.9 & 9.1 & 9.1 \\
\hline & Other regions & 49.4 & 49.7 & 50.1 & 49.7 & 49.1 & 48.5 & 48.3 & 47.9 & 47.9 & 54.4 & 53.2 & 52.9 & 53.0 & 52.7 & 53.5 & 53.2 & 52.7 & 52.7 \\
\hline \multirow{4}{*}{$\begin{array}{l}\frac{7}{0} \\
\frac{\pi}{0} \\
0\end{array}$} & Capital city regions & 16.0 & 16.4 & 16.5 & 16.7 & 16.1 & 17.0 & 17.2 & 17.4 & 17.1 & 10.2 & 9.5 & 9.4 & 9.4 & 9.8 & 9.7 & 10.4 & 10.7 & 11.0 \\
\hline & Second tier metro regions & 29.7 & 28.9 & 29.6 & 29.5 & 29.9 & 29.5 & 29.5 & 29.6 & 29.8 & 24.5 & 25.2 & 25.8 & 25.9 & 26.2 & 26.4 & 26.5 & 26.4 & 26.3 \\
\hline & Smaller metro regions & 23.1 & 23.1 & 22.8 & 22.6 & 22.5 & 22.2 & 21.9 & 21.8 & 22.1 & 25.5 & 25.6 & 25.3 & 25.2 & 25.0 & 24.8 & 24.5 & 24.3 & 24.2 \\
\hline & Other regions & 31.3 & 31.5 & 31.1 & 31.2 & 31.5 & 31.4 & 31.3 & 31.2 & 31.0 & 39.9 & 39.8 & 39.6 & 39.5 & 39.0 & 39.2 & 38.7 & 38.6 & 38.5 \\
\hline \multirow{4}{*}{ 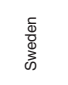 } & Capital city regions & 28.4 & 28.0 & 28.3 & 28.2 & 28.6 & 29.0 & 28.5 & 28.9 & 29.1 & 24.2 & 24.3 & 24.0 & 24.0 & 23.7 & 24.0 & 23.9 & 24.0 & 24.1 \\
\hline & Second tier metro regions & 28.2 & 28.3 & 28.1 & 28.3 & 28.0 & 28.0 & 28.2 & 28.4 & 27.8 & 28.7 & 29.1 & 29.2 & 29.2 & 29.4 & 29.6 & 29.7 & 29.7 & 29.6 \\
\hline & Smaller metro regions & $n / a$ & $\mathrm{n} / \mathrm{a}$ & $\mathrm{n} / \mathrm{a}$ & $\mathrm{n} / \mathrm{a}$ & $\mathrm{n} / \mathrm{a}$ & $n / a$ & $\mathrm{n} / \mathrm{a}$ & $\mathrm{n} / \mathrm{a}$ & $\mathrm{n} / \mathrm{a}$ & $\mathrm{n} / \mathrm{a}$ & $n / a$ & $n / a$ & $n / a$ & $n / a$ & $\mathrm{n} / \mathrm{a}$ & $n / a$ & $n / a$ & $\mathrm{n} / \mathrm{a}$ \\
\hline & Other regions & 43.5 & 43.6 & 43.6 & 43.5 & 43.4 & 43.0 & 43.3 & 42.7 & 43.1 & 47.1 & 46.6 & 46.8 & 46.8 & 46.9 & 46.5 & 46.4 & 46.3 & 46.3 \\
\hline
\end{tabular}

Typology based on the European Commission regional typologisation $\quad$ * Excluding data for Belarus and Russia

$\mathrm{n} / \mathrm{a}=$ No region in corresponding class in country

Data source: Eurostat

In a situation where increased concentration to merely one capital region can create an imminent risk of backfire in terms of bottlenecks, lack of labour, high inflation, urban sprawl and other such negative aspects that inevitably effect entire countries and not merely the concerned urban areas, a consolidated effort on spreading the risks could be viable. In a BSR context, increased emphasis on secondary metropolitan areas may be a first step on the path of aligning the needs for increased cohesion with the growth oriented demands of e.g. the EU 2020 Strategy. 


\section{CONCLUSION}

Despite radically differing development conditions, most parts of the BSR share a common agenda in that they are faced with increasing polarisation tendencies where particularly capital cities are consuming an ever growing chunk of their respective countries' development potential. At the same time such concentration is to a certain level justified from an economic point of view, as decreasing financial means combined with small size often imply that resources need to be concentrated in order to sustain global competitiveness. In such a policy setting, development policies that aim for increasing cohesion could be, and often are, viewed as counter effective.

This paper sought to address these dichotomous development challenges in the BSR by applying a focus on territorial specifities with a particular attention to secondary city development. Currently none of the BSR countries have clear-cut policy instruments directed particularly towards secondary cities.

The paper illustrated that in terms of cost-benefit, there exists a clear development rationale in supporting secondary cities as they in many BSR countries already today - regardless of the lack of apparent targeted policies - outperform their national capital regions in economic development. Even though such development policies could essentially be viewed as agglomerational ones, secondary city development actions may at the same time depending on the spatial context help to increase overall territorial cohesion in their respective countries. A better harvesting of the underutilised potential in secondary cities may thus be one step on the road in acknowledging the possibilities of turning geographic handicaps into future strengths.

\section{ACKNOWLEDGEMENTS}

This paper builds upon a previous contribution published by the author in the Informationen zur Raumentwicklung, Raumplanung und - Entwicklung in der Ostseeregion in 2009, and is further inspired by the work of Prof. Michael Parkinson and his colleagues in the ongoing ESPON project SGPTDE - Secondary Growth Poles in Territorial Development in Europe, to which the author is loosely attached in the capacity of a Sounding Board Member.

\section{PRINTED REFERENCES}

Baltic Development Forum, 2007, State of the Region report 2006. The Baltic Sea Region - Top of Europe in Global Competition, Copenhagen/Helsinki.

Baltic Development Forum, 2008, State of the Region report 2007. The Baltic Sea Region as a Place to Do Business, Copenhagen/Helsinki.

Dijkstra L., Poelman H., 2011, Regional typologies: a compilation, Regional Focus n ${ }^{\circ}$ 01/2011, Brussels: European Commission, DG Regio.

ESPON, 2011, SGPTDE - Secondary Growth Poles in Territorial Development in Europe, Applied Research 2013/1/11, Interim Report Version 28/02/2011.

European Commission, 2008, Green Paper on Territorial Cohesion. Turning territorial diversity into strength, Brussels, 6.10.2008, $\operatorname{COM}(2008) 616$ final.

European Commission, 2010, Investing in Europe's Future. 5th Report on Economic, Social and Territorial Cohesion, Luxembourg: Publications Office of the European Union. 
Groth N. (ed.), 2008, East West Window. Working Group 1: Regional Integration: Russia in the Baltic Sea Region. Copenhagen.

Hanell T., 2009, Economic Development of the BSR - Stubborn patterns despite rapid change, Informationen zur Raumentwicklung, Raumplanung und Entwicklung in der Ostseeregion, heft 8/9.2009, Bundesamt für Bauwesen und Raumordnung.

Hanell T., Neubauer J., 2005, Cities of the Baltic Sea Region-Development Trends at the Turn of the Millennium, Stockholm, Nordregio Report.

Hanell T., Neubauer J., 2006, Geographies of Knowledge Production in Europe, Nordregio WP 2006:3, Stockholm: Nordregio.

Schmitt P. et al., 2008, Exploring the Baltic Sea Region - On territorial capital and spatial integration, Stockholm: Nordregio Report.

\section{ELECTRONIC DATA SOURCES}

Eurostat: http://epp.eurostat.ec.europa.eu

OECD: http://www.oecd.org

United Nations Commodity Trade Statistics: http://www.un.org/

World Bank: http://www.worldbank.org/ 